\title{
Taxonomy of the crawling water beetle Haliplus zacharenkoi, with notes on its ecology, phenology, and distribution (Coleoptera: Haliplidae)
}

\author{
P.N. Petrov \& A.G. Kirejtshuk
}

\begin{abstract}
Petrov, P.N. \& Kirejtshuk, A.G. 2007. Taxonomy of the crawling water beetle Haliplus zacharenkoi, with notes on its ecology, phenology, and distribution (Coleoptera: Haliplidae). Zoosystematica Rossica, 16(2): 247-249.

A diagnosis of Haliplus zacharenkoi Gramma in Gramma \& Prisny, 1973 is given. The specimen labelled as holotype by the authors was collected in a locality different from that mentioned in the original description. Therefore, the lectotype is designated and the paralectotypes examined are listed. The ecology and phenology of the species are discussed, its distribution is reviewed.
\end{abstract}

P.N. Petrov, Moscow South-West Gymnasium 1543, ul. 26 Bakinskikh Komissarov 3-5, Moscow 119571, Russia.E-mail: tinmonument@gmail.com

A.G. Kirejtshuk, Zoological Institute, Russian Academy of Sciences, Universitetskaya nab. 1, St.Petersburg 199034, Russia.E-mail: agk@zin.ru, alexander_kirejtshuk@yahoo.com

Haliplus zacharenkoi Gramma in Gramma et Prisny, 1973 was described from SE Ukraine. The species was later referred to as described either by Gramma \& Prisny (e.g., Vondel, 1997) or by Gramma in Gramma \& Prisny (e.g., Gramma, 1998; Kirejtshuk \& Gramma, 2001). The authorship of Gramma was given in the key and accepted by the author of the name. We follow here this interpretation. Later the species was recorded from several localities in Ukraine (Gramma, 1998) and SW Russia (Minoransky, 1996; Kirejtshuk \& Gramma, 2001; Prokin et al., 2002; Vondel, 2003; Nilsson et al., 2005). Unfortunately, the type series of this species is insufficiently specified in the original description (Gramma \& Prisny, 1973), where all the material examined is listed in the "Distribution" section and partly listed again in the "Material Used" section, which consists of a single sentence: " 50 specimens, including the holotype, are stored in the collection of the Zoological Institute of the Academy of Sciences of the USSR, Leningrad." The "Distribution" section lists as many as 716 specimens examined by the authors of that work, and in the absence of any statements to the contrary all these specimens constitute the type series. The main Coleoptera collection of the Zoological Institute contains 96 specimens of $H$. zacharenkoi examined by V.N. Gramma before publication of the original description (including 10 specimens from the collection of V.B. Zacharenko, Kharkov, deposited, after his decease in 1993, in the Zoological Institute). The holotype is indicated in the "Distribution" section as belonging to a series collected at Zanki Station, Kharkov Province, whereas the specimen labelled as the holotype is from the Chernomorskiy Nature Reserve, Kherson Province. This labelled specimen cannot be regarded as a holotype and, therefore, the whole type series must be regarded as syntypes. The stability of nomenclature would benefit, if the type series of $H$. zacharenkoi is specified and a lectotype is designated. Here we designate a lectotype, list the examined paralectotypes, and review what is known of $H$. zacharenkoi.

\section{Haliplus zacharenkoi Gramma in Gramma et Prisny, 1973}

Lectotype (here designated): $\sigma^{\prime \prime}$ bearing our lectotype label, Ukraine, Kharkov Prov., Zanki Station, pod [small body of stagnant water] in the steppe, 11.XII.1972, Zoological Institute, St. Petersburg.

Paralectotypes kept at Zoological Institute, St. Petersburg. Kharkov Prov., Zanki Station: pod in the steppe, 19.V.1967 (1 specimen), 25.IV.1970 (2 specimens), 26.XI.1971 (18 specimens), 11.IV.1972 (1 pecimen), 11.XII.1972 (32 specimens); Kherson Prov., Chernomorskiy Nature Reserve, Solenoozyornyy Section, 8.V.1971 
(1 specimen), 8.III.1972 (1 specimen), 5.V.1972 (16 specimens, including the specimen, male, labelled as "holotype"), 8.V.1972 (8 specimens); same nature reserve, Ivanovo-Rybachenskiy [Ivanovo-Rybachiy in the original description] Section, 24.V.1971 (2 specimens), 16.VI.1971 (1 specimen), 25.VII.1971 (1 specimen); same nature reserve, 20.VI.1971 (1 specimen), 5.VIII.1971 ( 9 specimens), 5.V.1972 (1 specimen). All the labels listed in this and the following sections are translated from Russian. The material was collected by Gramma or is supposed to be collected by him, with the exception of specimens collected in 1971 in Chernomorskiy Nature Reserve: according to Gramma \& Prisny (1973), these specimens were collected by Shatokhin. Total: 96 specimens.

Diagnosis. Most specimens of $H$. zacharenkoi can be distinguished from other European species of the subgenus Haliplus Latreille, 1802 s. str. (sensu Holmen, 1987 and Vondel et al., 2006) by the absence of basal plicae on pronotum, as was stated by Gramma \& Prisny (1973). Nevertheless, as van Vondel (1997) noted, though specimens of $H$. zacharenkoi are supposed to have no basal plicae, they sometimes have "vague impressions in their place". A specimen with "traces of such plicae" was later examined by van Vondel (2003). The type series includes many such specimens, so the absence of basal plicae on pronotum often cannot be used as distinguishing character. In any case, basal plicae in $H$. zacharenkoi, if present, are relatively short and more vague than in any other species of the subgenus. Among the European species of the genus Haliplus Latreille, 1802, $H$. zacharenkoi is most similar to H. fluviatilis Aubé, 1836 and especially $H$. sibiricus Motschulsky, 1860 (syn. wehnckei Gerhardt, 1877, synonymy suspected by Holmen, 1987 and established by Lundmark et al., 2001). It can be distinguished from $H$. fluviatilis by the shape of the penis trunk (Figs 1,3) and the larger (usually termed "right") paramere (see Vondel, 1997; Vondel et al., 2006), as well as, in most cases, by the shape of proster-
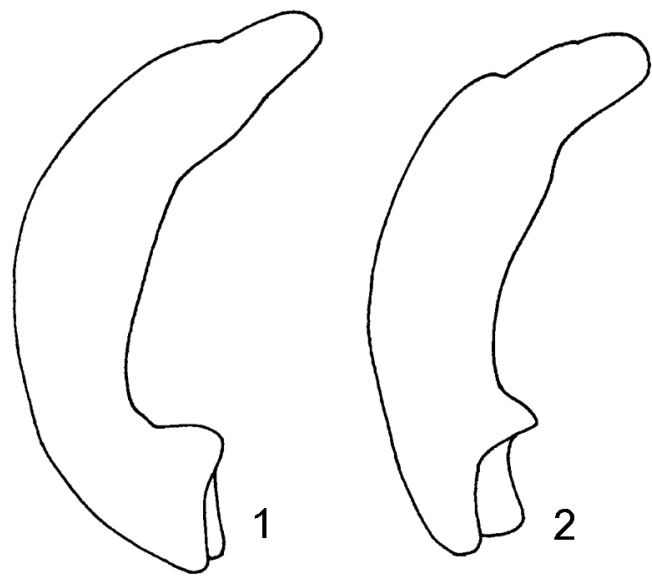

nal process, more or less flat in H. fluviatilis, and often (but not always) impressed medially in $H$. zacharenkoi. The body of $H$. fluviatilis is usually narrower and lower than in $H$. zacharenkoi. The variable male genital sclerites of $H$. sibiricus resemble those of $H$. zacharenkoi, but the narrow apical part of the penis trunk is, though varying in length, relatively shorter in $H$. zacharenkoi (Figs 2,3); the width of the penis trunk also varies, but in $H$. zacharenkoi it is usually greater than in $H$. sibiricus. As van Vondel (1997) observed, male protarsal claws in $H$. zacharenkoi are subequal in length, whereas $H$. sibiricus has the anterior claw shorter than posterior one. The prosternal process is sometimes flat in $H$. zacharenkoi, whereas in $H$. sibiricus it is always impressed medially, at least anteriorly (between procoxae). There are five more European species of Haliplus s. str. resembling $H$. zacharenkoi, $H$. fluviatilis, and $H$. sibiricus: H. lineolatus Mannerheim, 1844, H. immaculatus Gerhardt, 1877, H. ruficollis (De Geer, 1774), H. heydeni Wehncke, 1877, and H. interjectus Lindberg, 1937. Each of these five species can be distinguished from $H$. zacharenkoi by the same characters as from $H$. sibiricus (see Holmen, 1987; van Vondel, 1997; Kirejtshuk \& Gramma, 2001). None of the five species have the male genital sclerites similar to those of $H$. zacharenkoi. There are two East Palaearctic species of Haliplus s. str. lacking basal plicae on pronotum: H. simplex Clark, 1863 and H. harminae van Vondel, 1990, and another, recently described East Palaearctic species, H. fuscicornis Holmen, Vondel \& Petrov in Vondel et al., 2006, having short basal plicae, sometimes very short and resembling the "traces of plicae" in H. zacharenkoi. H. simplex can be distinguished from $H$. zacharenkoi by the presutural row of secondary punctures on elytron, dense and irregular in $H$. simplex, sparse and

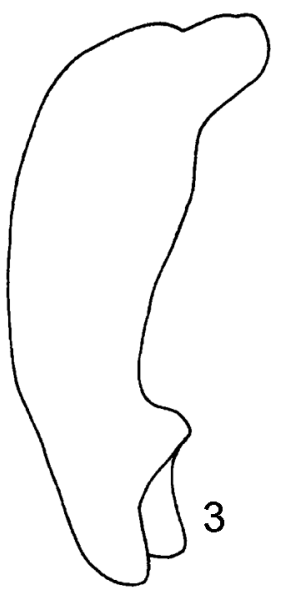
regular in $H$. zacharenkoi, and also by the male protarsal claws, subequal in $H$. zacharenkoi and clearly unequal in $H$. simplex (as in $H$. sibiricus). H. harminae differs from both $H$. simplex and $H$. zacharenkoi in the dark blotches on elytra, instead of parallel dark lines as in H. simplex and H. zacharenkoi (van Vondel, 1990). H. fuscicornis is distinct

Figs 1-3. Penis trunk of aedeagus, lateral. 1, Haliplus fluviatilis; 2, H. sibiricus; 3, H. zacharenkoi. 
from $H$. zacharenkoi in the protarsomere 1, bearing a sharp ventral ridge (as in H. immaculatus) in $H$. fuscicornis and without such ridge in $H$. zacharenkoi. $H$. simplex and $H$. fuscicornis can be distinguished from $H$. zacharenkoi also by the shape of the male genital sclerites (see Vondel et al., 2006); males of $H$. harminae are still unknown. Species of the subgenus Liaphlus Guignot, 1928 resemble $H$. zacharenkoi in the absence of the basal plicae on pronotum, but $H$. zacharenkoi can be easily diagnosed among the mentioned species by the absence of setiferous striole on the dorsal surface of metatibia (see Holmen, 1987; Vondel, 1997).

Ecology. Adults of this species usually occur in relatively small bodies of brackish and fresh stagnant water, temporary (especially in floodplains) and permanent, in steppe and forest-steppe. Some specimens were collected in slowly running water (Nilsson et al., 2005; Dyadichko \& Gramma, in prep.). The larva is unknown.

Phenology. Adult beetles were collected from mid-April to early August and from late November to mid-December. Thus, the species probably pupates in the autumn, with adults hibernating. It is possible that some of the larvae also hibernate, pupating in spring.

Distribution. Ukraine: Kharkov Prov. (Zanki, Zmiiv District), Dnepropetrovsk Prov. (Pavlohrad), Kherson Prov. (Chernomorskiy Nature Reserve; Askaniya-Nova Nature Reserve); Crimea Republic (Magazinka, Krasnoperekopsk District); Kirovograd and Odessa Prov. (data of Dyadichko \& Gramma, in prep.). Russia: Voronezh Prov. (Yarki near Yelan-Koleno, Novokhopersk District), Volgograd Prov. (city of Volgograd; Liska River, Liski District), Rostov Prov. (banks of the lower Don River and the Don delta).

\section{Acknowledgements}

We thank Bernhard J. van Vondel (Hendrik-IdoAmbacht, The Netherlands), who consulted us on the diagnostic characters of $H$. zacharenkoi, A.A. Prokin (Voronezh University, Russia) and O.G. Brekhov (Volgograd University, Russia), who helped us to locate the sites where the species was found in south-western Russia, V.G. Dyadichko (Odessa University, Ukraine) and V.N. Gramma (Kharkov Agricultural Institute, Ukraine), who kindly shared with us the data from the publication they prepare on this species. This study of A.G. Kirejtshuk was supported by the Programme of Presidium of the Russian Academy of Sciences "Origin and Evolution of the Biosphere" and grant of the Russian Foundation for
Basic Research (no. 070400540). The scientific collection of Zoological Institute, St. Petersburg, is supported by Rosnauka for UFC no. 2-2.20.

\section{References}

Gramma, V.M. [V.N.] 1998. New for the Crimea species of water beetles (Coleoptera: Haliplidae, Dytiscidae). Izv. Kharkov. Entomol. Obshch., 6(2): 41-42. (In Ukrainian).

Gramma, V.N. \& Prisny, A.V. 1973. A new species of the genus Haliplus Latr. (Coleoptera, Haliplidae) from the eastern Ukraine. Entomol. Obozr., 52(3): 637-643. (In Russian)

Holmen, M. 1987. The aquatic Adephaga (Coleoptera) of Fennoscandia and Denmark. I. Gyrinidae, Haliplidae, Hygrobiidae and Noteridae. Fauna Entomol. Scand., 20: $1-168$.

Kirejtshuk, A.G. \& Gramma, V.N. 2001. Family Haliplidae (crawling water beetles). In: Tsalolikhin, S.J. (Ed.). Opredelitel' presnovodnykh bespozvonochnykh Rossii i sopredel'nykh stran [Keys to freshwater invertebrates of Russia and adjacent lands], 5: 103-119, 464-495. Nauka, St. Petersburg. (In Russian).

Lundmark, M., Drotz, M.K. \& Nilsson, A.N. 2001. Morphometric and genetic analysis shows that Haliplus wehnckei is a junior synonym of $H$. sibiricus (Coleoptera: Haliplidae). Insect Syst. Evol., 32: 241-254.

Minoransky, V.A. 1996. Insects. In: Minoransky, V.A. (Ed.). Redkie, ischezayushchie i nuzhdayushchiesya $v$ okhrane zhivotnye Rostovskoy oblasti [Rare, disappearing and requiring conservation animals of Rostov Province]: 70-231. Rostov State University, Rostovon-Don. [In Russian.]

Nilsson, A.N., Bergsten, J. \& Brekhov, O. 2005. Water beetles from the Don River Basin, Volgograd province. Latissimus, 20: 38-44.

Prokin, A.A., Tsurikov, M.N., Negrobov, V.V. \& Grechanichenko, T.E. 2002. New data on the fauna of water beetles (Coleoptera) of the Central Chernozemny Region. In: Silina, A.Ye. \& Goncharuk, V.M. (Eds.). Gidrobiologicheskiye issledovaniya vodoemov Srednerusskoy lesostepi [Hydrobiological studies of waterbodies in the Central Russian Forest Steppe], 1: 19-54. Voronezh State University, Voronezh. (In Russian).

Vondel, B.J. van. 1990. Description of Haliplus harminae n. sp. from China (Coleoptera: Haliplidae). Entomol. Ber, 50(2): 22-24.

Vondel, B.J. van. 1997. Haliplidae. Süsswasserfauna von Mitteleuropa, 20(2): 1-95.

Vondel, B.J. van. 2003. Haliplus angusi van Vondel in Europe! Latissimus, 16: 25.

Vondel, B.J. van, Holmen, M. \& Petrov, P.N. 2006. Review of the Palaearctic and Oriental species of the subgenus Haliplus s. str. (Coleoptera: Haliplidae: Haliplus) with descriptions of three new species. Tijdschr. Entomol., 149: 227-273.

Received 15 August 2007 